\title{
Issues concerning scientific production of including people with disabilities at work
}

\author{
Guimarães, B. M ${ }^{\mathrm{a},{ }^{*}}$, Martins, L. B ${ }^{\mathrm{b}}$ and Barkokébas Junior, B \\ ${ }^{\mathrm{a}}$ Federal University of Pernambuco, Department of Design, Av. Prof. Moraes Rego, 1235, Cidade Universitária, \\ 50670-901,Recife-PE,Brazil.bmguimaraes@hotmail.com \\ ${ }^{\mathrm{b}}$ Federal University of Pernambuco, Department of Design, Av. Prof. Moraes Rego, 1235, Cidade Universitária, \\ 50670-901,Recife-PE, Brazil.laurabm@folha.rec.br \\ ${ }^{c}$ University of Pernambuco, Department of Civil Engeneering, Rua Benfica, 455, Bloco I - Madalena \\ 50720-001 - Recife, PE, Brazil. bedalsht@poli.br
}

\begin{abstract}
This article presents the results of a survey carried out on leading periodicals in the areas of Ergonomics, Physiotherapy and Occupational Therapy, the aim of which was to identify scientific publications on the inclusion at work of people with disabilities. The survey of articles published on this topic in the following journals was conducted in December 2010: Applied Ergonomics, Ergonomics, the International Journal of Industrial Ergonomics, Disability and Rehabilitation, and the Journal of Occupational Rehabilitation. The survey covered issues published between 2000 and 2010 and was conducted electronically using the CAPES Periodicals Portal. To collect the articles, it was necessary to check the articles published in each of the issues of each volume of these periodicals. This is how the articles on the topic in question were found. There were 27 articles on the topic of inclusion at work of people with disabilities, of which 13 were published in the Journal of Occupational Rehabilitation and 12 in Disability and Rehabilitation. Thus, it is clear that the issue in question is still a subject that is seldom dealt with in these publications and it is noted that only two articles were published in Ergonomics journals in this period, thus confirming the paucity of scientific publications on this subject.
\end{abstract}

Keywords: Ergonomics, person with disabilities, inclusion at work.

\section{Introduction}

About $23.9 \%$ of the population in Brazil, or 45.6 million people have some type of disability, of which $78 \%$ are visually impaired, $29.09 \%$ have a motor disability, $21.3 \%$ impaired hearing, $5.73 \%$ a mental disability (IBGE, 2011[7]).

Therefore, the inclusion of this population in the social-work environment has been widely discussed and encouraged at federal and state government levels by means of various laws and decrees. Among the legal measures adopted by the State, the ones that stand out are Law No. 8112, of 11/12/1990, which ensures people with a disability (PD) the right of $20 \%$ of the places offered in public competitive examinations being reserved for them and Law $8213 / 91$ which requires companies with more than 100 employees to have between $2 \%$ to $5 \%$ of people with disabilities in their workforce. Although these laws have encouraged the opening of places in companies, the number of PDs who participate in the labor market is still far below what is wished for (Tanaka, 2005 [4]).

Thus, it is noted that current legislation does not guarantee the inclusion of PDs in the labor market because, as per data from the 2009 Annual Report on Social Information (RAIS in Portuguese), of the total of 41.2 million active employees in formal employment at 31 December, 288,600 were declared as people with disabilities, which represents $0.7 \%$ of the total of those with legally-binding employment links to companies (Brazil, 2010 [3]).

As to the quota system, this shows that companies with more than 100 employees, representing about $10 \%$ of the total jobs in Brazil, the number of workers with disabilities who are formally employed by them has increased and in 2007 had reached $74.96 \%(261,458)$ of the 348,818 workers with disabilities in formal employment. In 2000, this proportion was $69 \%$ i.e. of workers who were in companies with more than 100 employees. This distribution is not linear in companies that are obliged

\footnotetext{
${ }^{*}$ Corresponding author: Guimarães, B. M. E-mail: bmguimaraes@hotmail.com
} 
to meet the quota. Some exceed the legal quotas and some are below them, while the largest companies meet the quota less than those with between 100 and 500 employees (Brazil, 2009 apud Vasconcelos, $2010[2])$.

It can be easily shown that the process of inclusion of people with disabilities in the labor market is a difficult task that has faced difficulties such as: the lack of professional training for people with disabilities, the presence of architectonic and organizational barriers, and discrimination with regard to their functional potential. Thus, it is essential to understand the interactions between people and the elements of the work system based on the foundations and methods of ergonomics so as to enable work to be suited to the functional capabilities of anyone who has a disability (Guimarães, 2011[1]).

Thus, ergonomics has become indispensable, since, through knowledge of the task, the physical, intellectual and organizational demands of jobs and by determining the functional capabilities of workers with disabilities, jobs can be properly adapted.

However, adapting jobs for people with disabilities can vary in terms both of the complexity of each case and of the resources needed. Consequently, planning each adaptation also varies as to the time, effort, and the range of professionals required, it being important that these should include physiotherapists, engineers, architects, designers and other professionals. Moreover, the process of adaptation should involve the people affected (the person with a disability, the employer and co-workers) by regarding them as participants who actively seek to achieve a good outcome (Martins e Guimarães, 2010 [6]).

With a view to contributing to knowledge of the process of including people with disabilities at work, the purpose of this paper is to present the survey carried out on leading periodicals in the fields of Ergonomics, Physiotherapy and Occupational Therapy with the goal of identifying papers in them on including people with disabilities at work.

\section{Method}

The survey of the articles published on the topic of the inclusion at work of people with disabilities was conducted in December 2010 on the following journals:

1. Applied Ergonomics;

2. Ergonomics;

3. International Journal of Industrial Ergonomics;

4. Disability and Rehabilitation;

\section{Journal of Occupational Rehabilitation.}

The option taken for selecting the journals is characterized as intentional and non-random. These periodicals were selected due to their importance to Ergonomics, Physiotherapy and Occupational Therapy.

As to the period covered, the survey took into account articles published in these journals between 2000 and 2010 and was conducted electronically using the CAPES Periodicals Portal (Portal de Periódicos da CAPES, 2010 [7]) which is a virtual library that collects and makes available to educational and research institutions in Brazil the best of national and international scientific production. To collect the articles, it was necessary to check the articles published in each of the issues of each volume of the periodicals. This is how the articles on the topic in question were found.

From reading and interpreting all the items in the sample, the first thing to be checked was the total number of articles published in the journals surveyed. Secondly, they were examined to determine the year of publication of each publication and the number of published articles per journal. After this step, it was sought to take a deeper look at the sample articles during which the methods and techniques the authors of these papers used were determined as were the countries in which they conducted them.

\section{Results}

From the data collected, 27 articles on the topic of inclusion of PDs at work were identified as having been published between 2000 and 2010, as can be seen in Figure 1. Thus, one can see that 2007 was the year with most publications on this theme, five in all, while for 2003 no articles were found in any of the journals surveyed. Despite the still small number of articles, it can be seen that this evolved mainly from 2007 , since in the last four years of the sample (20072010) 15 published articles were found, while between 2000 and 2006, 12 articles were identified. 


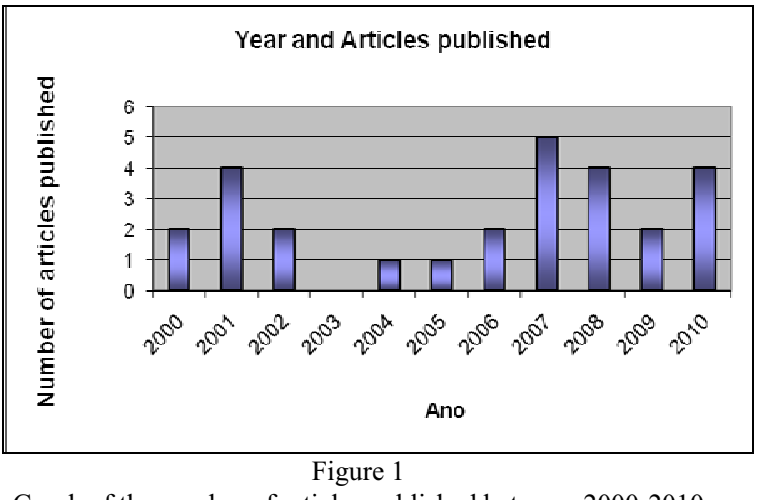

Graph of the number of articles published between 2000-2010

Most of the articles found between 2000 and 2010 were from journals in the fields of Physiotherapy and Occupational Therapy. It is observed that 13 articles were published in the Journal of Occupational Rehabilitation, which is equivalent to $48 \%$ of the sample and 12 articles were identified in the journal Disability and Rehabilitation, representing $44 \%$ of the total published. It is important to realize that if one adds up the number of articles published in these two journals, one obtains a total of $92 \%$ of the articles published in the five journals of the sample. It is seen that no article on the subject in question was found in the journal Ergonomics and only 1 item was found in Applied Ergonomics and one in the International Journal of Industrial Ergonomics, as shown in Figure 2.

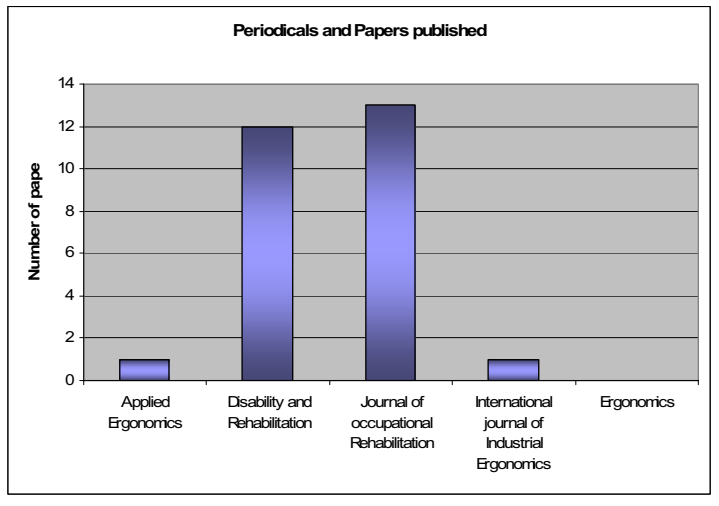

Figure 2

Graph of the number of articles published in the periodicals.

Among the articles found, 9 used Data Analysis from other surveys as methods and techniques and another 8 articles, a review of the literature. The use of interviews and questionnaires was found in 5 published papers, the conduct of an experiment in 4 and a case study in 2 published articles, as shown in Figure 3. Thus, it is clear that a small number of articles, only 6 , which equals $22 \%$ of the sample, conducted practical studies, in which the methods and techniques used were experiments or case studies.

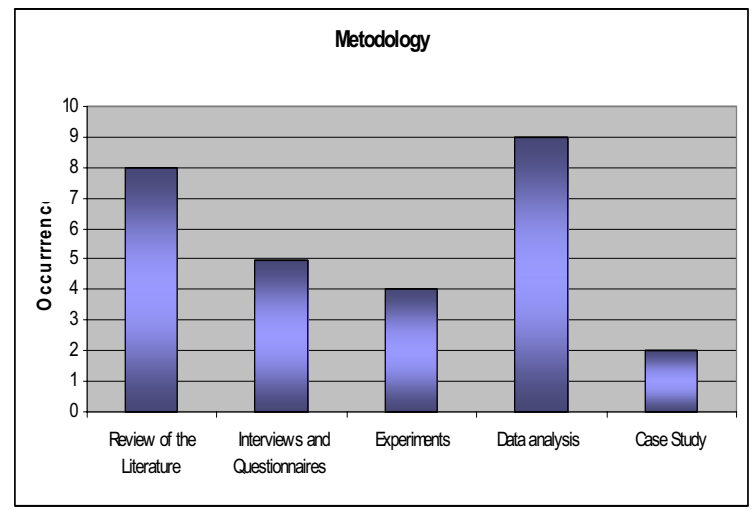

Figure 3

Graph of the methods and techniques used

From the results of this research, the graph of Figure 4 was also built which shows where the surveys were conducted. This shows that the country with most publications on the subject was the United States (USA) with 10 articles, followed by Holland, Taiwan and Canada with three items each. 2 articles written in Japan were found and one article came from each of Israel, Norway, United Kingdom, Scotland, Slovenia and Sweden.

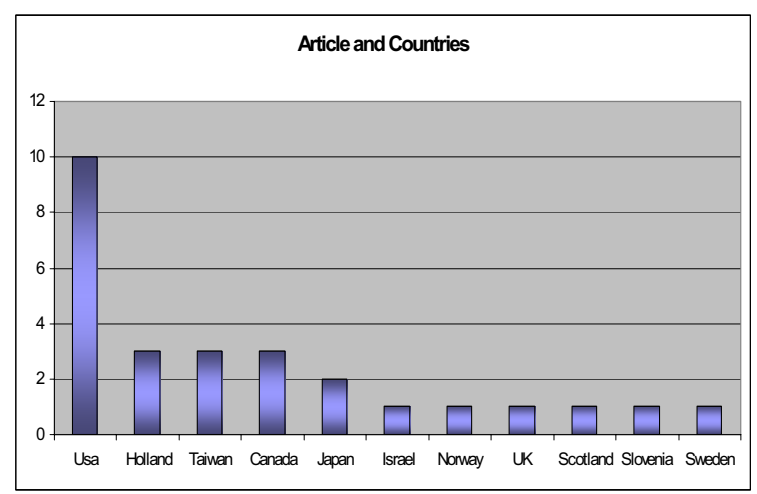

Figure 4

Graph of the place where the articles published were written

The full list of the 27 articles found in the journals surveyed can be seen in Tables 1, 2, 3 and 4 which give the title of the article, the authors, where the 
research was performed, the year of publication and the methods and techniques used.

Table 1

Applied Ergonomics (2000-2010)

\begin{tabular}{|l|l|l|l|l|}
\hline Title of the article & Authors & Place & $\begin{array}{l}\text { Year of publication / } \\
\text { Volume / Number }\end{array}$ & Methods and Techniques \\
\hline $\begin{array}{l}\text { Design and feasibility } \\
\text { study of an integrated } \\
\text { pointing device apparatus } \\
\text { for individuals with spinal } \\
\text { cord injury. }\end{array}$ & $\begin{array}{l}\text { Hsieh-Ching Chena, } \\
\text { Yung-Ping Liua, } \\
\text { Chia-Ling Chenb, } \\
\text { Chih-Yong Chenc }\end{array}$ & Taiwan & 2007 & Experiment \\
Volume: 38 & & & \\
\hline
\end{tabular}

Table 2

International Journal of Industrial Ergonomics (2000-2010)

\begin{tabular}{|l|l|l|l|l|}
\hline Title of the article & Authors & Place & $\begin{array}{l}\text { Year of publication / } \\
\text { Volume / Number }\end{array}$ & Methods and Techniques \\
\hline $\begin{array}{l}\text { The development of a } \\
\text { hierarchical coding } \\
\text { scheme and database } \\
\begin{array}{l}\text { of job accommodation for } \\
\text { disabled workers. }\end{array}\end{array}$ & $\begin{array}{l}\text { Chia-Fen Chia, } \\
\text { Jung-Shung Pana, } \\
\text { Tzu-Hsin Liua, } \\
\text { Yuh Jangb }\end{array}$ & Taiwan & 2007 & Review of the Literature and experiment \\
Volume 33 & Number:5 & \\
\hline
\end{tabular}

Table 3

Disability and Rehabilitation (2000-2010)

\begin{tabular}{|c|c|c|c|c|}
\hline Title of the article & Authors & Place & $\begin{array}{l}\text { Year of publication / } \\
\text { Volume / Number }\end{array}$ & Methods and Techniques \\
\hline $\begin{array}{l}\text { A preliminary examination of the } \\
\text { relationship between employment, } \\
\text { pain and disability in an amputee } \\
\text { population. }\end{array}$ & $\begin{array}{l}\text { A. S. Whyte, } \\
\text { L. J. Carroll }\end{array}$ & Scotland & $\begin{array}{l}2002 \\
\text { Volume: } 24 \\
\text { Number: } 9\end{array}$ & Questionnaire \\
\hline $\begin{array}{l}\text { Access to employment for people } \\
\text { with disabilities: findings of a } \\
\text { consumer-led project. }\end{array}$ & Jill E. Robinson & $\begin{array}{l}\text { United } \\
\text { Kingdom }\end{array}$ & $\begin{array}{l}2000 \\
\text { Volume: } 22 \\
\text { Number: } 5\end{array}$ & Semi-structured interviews \\
\hline $\begin{array}{l}\text { Disability management after stroke: } \\
\text { its medical aspects for workplace } \\
\text { accommodation. }\end{array}$ & Satoru Saeki & Japan & $\begin{array}{l}2000 \\
\text { Volume: } 22 \\
\text { Number: } 13 / 14\end{array}$ & Review of the Literature \\
\hline $\begin{array}{l}\text { Disability, injury and ergonomics } \\
\text { intervention. }\end{array}$ & Shrawan Kumar & Canada & $\begin{array}{l}2001 \\
\text { Volume: } 23 \\
\text { Number: } 18\end{array}$ & $\begin{array}{l}\text { Review of the Literature and } 2 \\
\text { case studies. }\end{array}$ \\
\hline $\begin{array}{l}\text { Employers and policy makers can } \\
\text { make a difference to the } \\
\text { employment of persons with } \\
\text { disabilities. }\end{array}$ & $\begin{array}{l}\text { M. G. Westmorland, } \\
\text { R. Williams }\end{array}$ & Canada & $\begin{array}{l}2002 \\
\text { Volume: } 24 \\
\text { Number } 15\end{array}$ & Review of the literature \\
\hline
\end{tabular}




\begin{tabular}{|c|c|c|c|c|}
\hline $\begin{array}{l}\text { Job coach factors associated with } \\
\text { community-based employment } \\
\text { service programme outcome } \\
\text { measures for people with } \\
\text { disabilities - a Taiwan case study. }\end{array}$ & Wang Yu-Tung & Taiwan & $\begin{array}{l}2010 \\
\text { Volume: } 32 \\
\text { Number: } 19\end{array}$ & Data analysis \\
\hline $\begin{array}{l}\text { Predictors of return to work } \\
\text { following traumatic work-related } \\
\text { lower extremity amputation. }\end{array}$ & $\begin{array}{l}\text { Jackie S. Hebert, } \\
\text { Nigel L. Ashworth }\end{array}$ & Canada & $\begin{array}{l}2006 \\
\text { Volume: } 28 \\
\text { Number: } 10\end{array}$ & Data analysis \\
\hline $\begin{array}{l}\text { Stroke patients' experiences of } \\
\text { return to work. }\end{array}$ & $\begin{array}{l}\text { Jennie Medin, } \\
\text { Josefin Barajas, } \\
\text { Kerstin Ekberg }\end{array}$ & Sweden & $\begin{array}{l}2006 \\
\text { Volume: } 28 \\
\text { Number: } 17\end{array}$ & Interviews \\
\hline Partial hand amputation and work. & $\begin{array}{l}\text { Helena Burger, } \\
\text { Tomaz Maver, } \\
\text { C.R.T. Marincek }\end{array}$ & Slovenia & $\begin{array}{l}2007 \\
\text { Volume: } 29 \\
\text { Number: } 17\end{array}$ & $\begin{array}{l}\text { Data analysis and } \\
\text { questionnaire. }\end{array}$ \\
\hline $\begin{array}{l}\text { Return to work following traumatic } \\
\text { brain injury: Trends and } \\
\text { challenges. }\end{array}$ & $\begin{array}{l}\text { Jeffrey Shames, } \\
\text { Iuly Treger, } \\
\text { Haim Rindg, } \\
\text { Salvatore Giaquinto }\end{array}$ & Israel & $\begin{array}{l}2007 \\
\text { Volume: } 29 \\
\text { Number: } 17\end{array}$ & Review of the literature \\
\hline $\begin{array}{l}\text { Return to work following spinal } \\
\text { cord injury: a review. }\end{array}$ & $\begin{array}{l}\text { Inceborg Beate } \\
\text { Lindal, } \\
\text { Tuan Khai Huynh, } \\
\text { Fin Biering- } \\
\text { Sørensen }\end{array}$ & Norway & $\begin{array}{l}2007 \\
\text { Volume: } 29 \\
\text { Number: } 17\end{array}$ & Review of the literature \\
\hline $\begin{array}{l}\text { Examining the impact of physical } \\
\text { and sexual abuse on the } \\
\text { employment of women with } \\
\text { disabilities in the United States: } \\
\text { An exploratory analysis. }\end{array}$ & $\begin{array}{l}\text { Diane L. Smith, } \\
\text { David R. Strauser }\end{array}$ & USA & $\begin{array}{l}2008 \\
\text { Volume: } 30 \\
\text { Number } 14\end{array}$ & Data analysis \\
\hline
\end{tabular}

Table 4

Journal of Occupational Rehabilitation (2000-2010)

\begin{tabular}{|c|c|c|c|c|}
\hline Title of the article & Authors & Place & $\begin{array}{l}\text { Year of publication / } \\
\text { Volume / Number }\end{array}$ & Methods and Techniques \\
\hline $\begin{array}{l}\text { Age and Disability Employment } \\
\text { Discrimination: Occupational } \\
\text { Rehabilitation Implications. }\end{array}$ & $\begin{array}{l}\text { Melissa J. Bjelland, } \\
\text { Susanne M. Bruyère, } \\
\text { Sarah von Schrader, } \\
\text { Andrew J. Houtenville, } \\
\text { Antonio Ruiz- } \\
\text { Quintanilla, } \\
\text { Douglas A. Webber }\end{array}$ & USA & $\begin{array}{l}2010 \\
\text { Volume: } 20 \\
\text { Number: } 4\end{array}$ & Data analysis \\
\hline $\begin{array}{l}\text { Assessment of Functional Capacity } \\
\text { of the Musculoskeletal } \\
\text { System in the Context of Work, } \\
\text { Daily Living, and Sport: } \\
\text { A Systematic Review. }\end{array}$ & $\begin{array}{l}\text { HaijeWind, } \\
\text { Vincent Gouttebarge, } \\
\text { P. Paul F.M. Kuijer, } \\
\text { Monique H.W. Frings- } \\
\text { Dresen }\end{array}$ & Holland & $\begin{array}{l}2005 \\
\text { Volume: } 15 \\
\text { Number: } 2\end{array}$ & Review of the literature \\
\hline $\begin{array}{l}\text { Employment and Disability: } \\
\text { Evidence From the } 1996 \text { Medical } \\
\text { Expenditures Panel Survey. }\end{array}$ & $\begin{array}{l}\text { Patricia A. Findley, } \\
\text { Usha Sambamoorthi }\end{array}$ & USA & $\begin{array}{l}2004 \\
\text { Volume: } 14 \\
\text { Number: } 1\end{array}$ & Questionnaire \\
\hline
\end{tabular}




\begin{tabular}{|c|c|c|c|c|}
\hline $\begin{array}{l}\text { Factors that Promote or Hinder } \\
\text { Young Disabled People } \\
\text { in Work Participation: A } \\
\text { Systematic Review. }\end{array}$ & $\begin{array}{l}\text { T. J. Achterberg, } \\
\text { H. Wind, } \\
\text { A. G. E. M. de Boer, } \\
\text { M. H. W. Frings-Dresen }\end{array}$ & Holland & $\begin{array}{l}2009 \\
\text { Volume: } 19 \\
\text { Number: } 2\end{array}$ & Review of the literature \\
\hline $\begin{array}{l}\text { Vocational Rehabilitation Services } \\
\text { and Employment Outcomes } \\
\text { for People with Disabilities: A } \\
\text { United States Study. }\end{array}$ & $\begin{array}{l}\text { Alo Dutta, } \\
\text { Robert Gervey, } \\
\text { Fong Chan, } \\
\text { Chih-Chin Chou, } \\
\text { Nicole Ditchman }\end{array}$ & USA & $\begin{array}{l}2008 \\
\text { Volume: } 18 \\
\text { Number: } 4\end{array}$ & Data analysis \\
\hline $\begin{array}{l}\text { A Literature Review Describing the } \\
\text { Role of Return-to-Work } \\
\text { Coordinators in Trial Programs and } \\
\text { Interventions Designed } \\
\text { to Prevent Workplace Disability. }\end{array}$ & $\begin{array}{l}\text { William Shaw, } \\
\text { Quan-nha Hong, } \\
\text { Glenn Pransky, } \\
\text { Patrick Loisel }\end{array}$ & USA & $\begin{array}{l}2008 \\
\text { Volume: } 18 \\
\text { Number: } 1\end{array}$ & Review of the literature \\
\hline $\begin{array}{l}\text { Design Guidelines for } \\
\text { Accommodating Amputees in the } \\
\text { Workplace. }\end{array}$ & $\begin{array}{l}\text { A. Girdhar, } \\
\text { A. Mital, } \\
\text { A. Kephart, } \\
\text { A. Young }\end{array}$ & USA & $\begin{array}{l}2001 \\
\text { Volume: } 11 \\
\text { Number: } 2\end{array}$ & Review of the literature \\
\hline $\begin{array}{l}\text { Hiring Discrimination Against } \\
\text { People with Disabilities Under the } \\
\text { ADA: Characteristics of } \\
\text { Employers. }\end{array}$ & $\begin{array}{l}\text { Brian T. McMahon, } \\
\text { Philip D. Rumrill Jr, } \\
\text { Richard Roessler, } \\
\text { Jessica E. Hurley, } \\
\text { Steven L. West, } \\
\text { Fong Chan, } \\
\text { Linnea Carlson }\end{array}$ & USA & $\begin{array}{l}2008 \\
\text { Volume: } 18 \\
\text { Number: } 2\end{array}$ & Data analysis \\
\hline $\begin{array}{l}\text { Performance Reduction in Finger } \\
\text { Amputees When Reaching and } \\
\text { Operating Common Control } \\
\text { Devices: A Pilot Experimental } \\
\text { Investigation Using a Simulated } \\
\text { Finger Disability. }\end{array}$ & $\begin{array}{l}\text { Arunkumar Pennathur, } \\
\text { Anil Mital, } \\
\text { Luis Rene Contreras }\end{array}$ & USA & $\begin{array}{l}2001 \\
\text { Volume: } 11 \\
\text { Number: } 4\end{array}$ & Experiment \\
\hline $\begin{array}{l}\text { Reliability and Validity of the } \\
\text { Disability Assessment Structured } \\
\text { Interview (DASI): A Tool } \\
\text { for/Assessing Functional } \\
\text { Limitations in Claimants. }\end{array}$ & $\begin{array}{l}\text { Jerry Spanjer, } \\
\text { Boudien Krol, } \\
\text { Sandra Brouwer, } \\
\text { Roel Popping, } \\
\text { Johan W. Groothoff, } \\
\text { Jac J. L. van der Klink } \\
\end{array}$ & Holland & $\begin{array}{l}2010 \\
\text { Volume: } 20 \\
\text { Number: } 1\end{array}$ & Experiment \\
\hline $\begin{array}{l}\text { Stuck at the Bottom Rung: } \\
\text { Occupational Characteristics of } \\
\text { Workers with Disabilities. }\end{array}$ & H. Stephen Kaye & USA & $\begin{array}{l}2009 \\
\text { Volume: } 19 \\
\text { Number: } 2\end{array}$ & Data analysis \\
\hline $\begin{array}{l}\text { What Types of Jobs Do People } \\
\text { with Disabilities Want? }\end{array}$ & $\begin{array}{l}\text { Mohammad Ali, } \\
\text { Lisa Schur, } \\
\text { Peter Blanck }\end{array}$ & USA & $\begin{array}{l}2010 \\
\text { Volume: } 20\end{array}$ & Data analysis \\
\hline $\begin{array}{l}\text { Workplace Disability Management } \\
\text { in Post-polio Syndrome. }\end{array}$ & $\begin{array}{l}\text { Satoru Saeki, } \\
\text { Jin Takemura, } \\
\text { Yasuyuki Matsushima, } \\
\text { Hiromi Chisaka, } \\
\text { Kenji Hachisuka }\end{array}$ & Japan & $\begin{array}{l}2001 \\
\text { Volume: } 11 \\
\text { Number: } 4\end{array}$ & Case study \\
\hline
\end{tabular}


http://www2.periodicos.capes.gov.br/portugues/index.jsp?urlo rigem $=$ true

\section{Discussion}

The data found in this survey are important considering that, in the last 20 or so years, society has been discussing ways to include people with disabilities both in the social environment and at work.

Thus, it is clear that the theme of the inclusion at work of people with disabilities is still a subject that is seldom tackled in articles in Ergonomics journals, since only 27 papers published between 2000 and 2010 were found in the journals surveyed. It is also noted that only 2 papers were published in Ergonomics journals in this period, thus confirming the paucity of scientific publications on this subject under an ergonomic approach.

From the survey, it can be stated that no articles were found on the inclusion at work of people with disabilities, in Brazil, thus confirming the lack as to the production of research studies that address this issue from the standpoint of Ergonomics, especially with regard to analyzing and adapting jobs for PDs, in Brazil.

Thus, it has been shown that the aim of the survey was achieved, since evidence was provided as to the importance of the survey, since it reveals a lack of scientific articles in the journals surveyed on the inclusion at work of people with disabilities.

\section{References}

[1] B.M. Guimarães, Exigências da tarefa e o perfil dos trabalhadores com deficiência: um estudo de caso na construção civil usando o software ErgoDis/IBV. Master's. Dissertation, University of Pernambuco, 2011.

[2] Brasil. Decreto $\mathrm{n}^{\circ}$ 3.298, de 20 de dezembro de 1999. Available at: http://www.planalto.gov.br/

[3] Brasil. Ministério do Trabalho e Emprego. RAIS - Relação Anual de Informações Sociais, 2000 a 2009. Available at: $<$ http://www.mte.gov.br/pdet/index.asp $>$. Accessed on: 01 Nov. 2010.

[4] E.D.O.M. Tanaka, J.O. Eduardo, O que os empregadores pensam sobre o trabalho da pessoa com deficiência? Revista Brasileira de Educação Especial, Marília, v. 11, n. 2, 2005, pp. 273-294.

[5] IBGE - Instituto Brasileiro de Geografia e Estatística Tabulação Avançada do Censo Demográfico 2010. Rio de Janeiro: IBGE, 2011.

[6] L.B. Martins; B.M. Guimarães, Ergonomia e a inclusão laboral de pessoas com deficiência. Revista Brasileira de Tradução Visual. v. 3, n. 3, 2010.

[7] Portal de Periódicos da CAPES [accessed on 02 Dec. 2010]. Available at: 